\title{
SUMBER DAYA MANUSIA SEBAGAI SUMBER KEUNGGULAN KOMPETITIF
}

\author{
KASMAWATI \\ Fakultas Tarbiyah dan Keguruan UIN Alauddin Makassar \\ JI. HM. Yasin Limpo No. 36 Makassar \\ Email: kasmawati6131@gmail.com
}

\begin{abstract}
Abstrak
The competition between companies or institutions today requires companies or institutions to be able to survive and compete with other companies. One of the things that can be taken by the company to be able to survive in intense competition is human resources. The role of human resources in the company is very important because the main driver of all activities the company in achieving its goals both to gain profits and to maintain the survival of the company are humans. The success or failure of a company in maintaining the existence of the company starts from the human effort itself in maximizing effectiveness and efficiency. In other words, the performance of an organization or company is highly influenced and even depends on the quality and competitive ability of its human resources. The purpose of the company in standardizing or benchmarking so that human resources or labor obtained can really work in accordance with what is desired by the company.
\end{abstract}

Keywords: Human Resource Management, Source of Competitive Advantage

\section{PENDAHULUAN}

$\mathrm{M}$ emasuki abad ke-21, pengaruh globalisasi yang melanda dunia semakin dalam menyentuh sisi-sisi kehidupan perusahaan. Perkembangan teknologi informatika yang sangat cepat dan luas menciptakan peluangpeluang yang sekaligus juga merupakan tantangan-tantangan bagi perusahaan. Peluang-peluang yang diciptakan perkembangan teknologi informatika ini, diantaranya adalah semakin meluasnya kesempatan pasar bagi perusahaan, akses terhadap sumberdaya yang semakin mudah dan semakin beragam, dan semakin terbukanya kemungkinan untuk menciptakan aliansi dan kerja sama dengan perusahaan-perusahaan luar negeri. Namun di lain pihak, globalisasi juga memberikan tantangan-tantangan yang harus dijawab oleh perusahaan dengan baik. Tantangan-tantangan tersebut adalah adanya perbedaan preferensi konsumen yang berasal dari berbagai teritorial dan latar belakang budaya, tantangan yang ditimbulkan oleh keberagaman satuan kerja (work diversity), dan meningkatnya intensitas persaingan global. Meningkatnya intensitas persaingan global menempatkan perusahaan dan para manajer pada posisi yang tertekan, yang menuntut mereka untuk mampu mengambil keputusan-keputusan bisnis secara lebih cepat, lebih tepat dan lebih baik. Di samping itu, perusahaan-perusahaan dituntut untuk memiliki keunggulan-keunggulan, terutama di bidang SDM dan bagaimana SDM tersebut dikelola. Keunggulan-keunggulan yang diperoleh melalui kepemilikan SDM-SDM unggul, merupakan asset terpenting perusahaan, karena sumberdaya manusia adalah satu-satunya tempat di mana asset pengetahuan 
(knowledge) melekat (Lancourt dan Savage, 1995). Namun demikian, persoalan bagaimana SDM-SDM tersebut dikelola dengan baik, adalah kontributor yang lebih penting lagi bagi perusahaan dalam rangka mencapai kinerja yang tinggi.

Pendekatan Resource-Based View memandang bahwa sumberdaya perusahaan yang dapat digunakan dalam mencapai keunggulan kompetitif terdiri dari sumber daya modal fisik, sumber daya modal perusahaan, dan SDM. Potensi asset SDM untuk mencapai keunggulan kompetitif ini telah merangsang minat banyak ilmuan. Lado dan Wilson (1994) menyatakan bahwa kinerja MSDM sangat potensial dalam membantu perusahaan untuk mencapai keunggulan kompetitifnya, sedangkan Jackson dan Schuler (1995) menghubungkan the resource-based view dengan organizational learning.

Konsep MSDM sebagai asset strategis, memiliki implikasi baik pada karateristik maupun sistem yang ada dalam organisasi. Asset strategis MSDM merupakan kemampuan yang sulit ditiru, langka, tepat guna, dan yang secara khusus memberikan keunggulan kompetitif bagi karyawan. Tidak seperti investasi modal, economic scale atau hak patent, sistem MSDM yang dikembangkan dengan baik bisa menjadi asset yang tidak kelihatan (Intangible) dan mampu menciptakan nilai (Valuable) apabila diterapkan dalam sistem operasional organisasi sehingga bisa meningkatkan kemampuan perusahaan saat ini. Sumber keunggulan kompetitif melalui praktik-praktik MSDM dapat dipertahankan dengan dua alasan. Pertama, mengelola SDM secara efektif sering tidak setransparan sumbernya, artinya budaya dan praktik yang memampukan perusahaan mencapai kesuksesan tidak tampak nyata bila dibandingkan dengan melihat sistem informasi yang terkomputerisasi. Kedua, cara bagaimana SDM dikelola secara sinergis sesuai dengan sistemnya tidak mudah ditiru oleh organisasi lain. Dengan demikian praktik-praktik dan sistem SDM dapat memegang peranan penting bagi keberhasilan perusahaan

\section{PEMBAHASAN}

\section{Peran, Fungsi-Fungsi SDM dalam Lembaga Pendidikan}

Porter (1998) mengatakan bahwa MSDM dapat membantu sebuah perusahaan memperoleh keunggulan kompetitif dengan menurunkan biaya, meningkatkan sumber-sumber produk dan perbedaan layanan, atau dengan keduaduanya. Pencapaian keunggulan kompetitif melalui SDM memerlukan aktivitasaktivitas yang dikelola dengan perspektif strategik.

Keberhasilan dalam berkompetisi di pasar membutuhkan strategi yang dinyatakan dengan jelas. Supaya strategi dapat diterapkan dengan sukses, karyawan harus memerankan perilaku tertentu. Manajemen berperan untuk merangsang perilaku tersebut melalui kebijakan-kebijakan dan program-programnya. Strategi bersaing yang dapat dilakukan oleh perusahaan adalah:

1. Strategi inovasi yang menekankan pada penawaran produk dan jasa baru. Strategi ini memerlukan keberanian mengambil risiko dan mentoleransi 
kegagalan yang tidak bisa dihindarkan. Karena itu praktik MSDM dalam perusahaan yang melakukan strategi ini harus diupayakan untuk memberikan rasa aman karyawan dan merangsang orientasi jangka panjang mereka.

2. Perbaikan mutu, fokus pada konsumen, penekanan pada mutu barang dan jasa yang dihasilkan guna memuaskan konsumen.

3. Pengurangan biaya agar dapat menghasilkan produk yang relatif murah. Oleh karena itu perusahaan perlu berusaha meningkatkan efisiensi. Untuk mencapainya, biasanya mereka akan menurunkan biaya produksi, khususnya biaya karyawan karena ini merupakan komponen biaya terbesar bagi perusahaan. Akibatnya akan terjadi pemutusan hubungan kerja. Cara lainnya adalah dengan menerima pekerja part time dan pekerja subkontrak.

Fungsi MDSM merupakan salah satu fungsi bisnis yang harus ditangani para manajer, di samping fungsi-fungsi lainnya seperti fungsi pemasaran, operasional, keuangan, dan bidang-bidang fungsional lainnya. Secara tradisional, fungsi MSDM dipandang sebagai bidang fungsional yang harus memberikan pelayanan bagi fungsifungsi lainnya. Pelayanan ini mulai dari perekrutan karyawan yang akan bekerja pada bidang-bidang fungsional tersebut , mempersiapkan mereka, memotivasi, mendistribusikan dan mengadministrasikan kompensasi dan insentif, hingga mengupayakan agar orang-orang yang memiliki kompetensi tetap bergabung dalam organisasi.

Ketika para praktisi organisasi semakin menyadari peran penting kebijakankebijakan dan praktik-praktik MSDM dalam meningkatkan kinerja organisasional, maka peran yang diberikan pada fungsi ini semakin strategis. Untuk menganalisa peran MSDM, salah satu pendekatan yang dapat digunakan adalah pendekatan rantai nilai (value-chain) yang dikemukakan oleh Porter (1998). Seperti yang terlihat pada gambar 1, fungsi MSDM bersama-sama dengan infrastruktur perusahaan, pengembangan teknologi, dan fungsi pembelian merupakan kegiatan-kegiatan pendukung (support activities) dalam rantai nilai perusahaan.

Menurut Porter, setiap perusahaan merupakan suatu rangkaian aktivitas yang dilakukan untuk merancang, memproduksi, memasarkan, menyampaikan, dan mendukung produk-produknya. Setiap rantai nilai merupakan total nilai, yang terdiri atas aktivitas-aktivitas yang bernilai dan laba. Aktivitas-aktivitas yang berada dalam rangkaian tersebut merefresentasikan nilai yang ditujukan untuk memberikan laba bagi perusahaan. Aktivitas-aktivitas nilai ini terdiri dari aktivitas-aktivitas utama, dan aktivitas-aktivitas pendukung. MSDM mempengaruhi keunggulan kompetitif perusahaan melalui perannya dalam menentukan keahlian-keahlian dan motivasi karyawan serta biaya perekrutan dan pelatihan. Dalam beberapa sektor industri, MSDM memainkan peran kunci untuk mencapai keunggulan kompetitif.

Keputusan-keputusan MSDM ada dalam berbagai bagian perusahaan. MSDM merupakan aktivitas nilai yang berfungsi untuk mendukung aktivitas-aktivitas utama secara individual dan aktivitas-aktivitas pendukung lainnya, maupun keseluruhan 
rantai nilai perusahaan. Karenanya, kelancaran dan keberlanjutan kontribusi aktivitas-aktivitas nilai lainnya, baik aktivitas utama maupun aktivitas pendukung, terhadap keunggulan kompetitif perusahaan sangat tergantung pada keefektivan dan efisiensi fungsi MSDM. Sebagai contoh, fungsi MSDM harus merekrut karyawankaryawan yang kompeten untuk menangani dan menjalankan aktivitas-aktivitas nilai lainnya melalui analisis pekerjaan yang akurat, mempersiapkan mereka untuk kebutuhan operasional saat ini dan masa yang akan datang melalui programprogram pelatihan dan pengembangan, mengupayakan mereka memiliki motivasi yang tinggi melalui program manajemen karir, tingkat kompensasi dan insentif yang tepat, mengevaluasi dan menilai kinerja mereka agar setiap individu dan setiap aktivitas nilai tersebut berkontribusi, dan mengupayakan agar orang-orang yang memiliki kompetensi tetap bergabung dalam organisasi dan menciptakan kepuasan dan komitmen karyawan dan lain sebagainya.

Byar dan Rue (2000: 97) mengidentifikasi 3 bentuk dukungan yang diberikan departemen SDM kepada departemen-departemen operasional dalam perusahaan, yaitu dukungan saran (advice), pelayanan-pelayanan khusus (specific services), dan koordinasi (coordination).

Umumnya, manajer SDM bertindak sebagai penasehat (adviser) dan tidak memiliki wewenang langsung atas manajer-manajer lini. Kondisi ini, terkadang menimbulkan konflik, terutama ketika manajer lini mengabaikan saran-saran dan rekomendasi departemen SDM. Dengan kapasitasnya sebagai penasehat ini, departemen SDM harus mampu memfasilitasi terpelihara dan terpenuhinya prosedur-prosedur organisasional, terpeliharanya sistem nilai dan budaya perusahaan, terpenuhinya aturan-aturan yang berkaitan dengan perundangundangan, terbinanya hubungan yang baik dan sehat dengan para karyawan, dan lain sebagainya.

Fungsi kedua departemen SDM adalah sebagai penyedia jasa-jasa spesifik bagi departemen-departemen operasional, seperti penyediaan basis data (database) informasi tentang karyawan-karyawan perusahaan, melakukan perekrutan, seleksi dan wawancara bagi karyawan baru, menyelenggarakan pelatihan dan orientasi, menangani keluhan-keluhan dan pengaduan karyawan dan lain sebagainya. Kegiatan-kegiatan ini pada dasarnya merupakan wewenang dan tanggung-jawab departemen SDM. Kegiatan-kegiatan tersebut dapat dilaksanakan sendiri oleh departemen SDM atau dapat pula diserahkan (outsourcing) kepada pihak luar perusahaan untuk melakukannya. Namun demikian, jika diputuskan bahwa kegiatan-kegiatan tersebut diserahkan pada pihak luar perusahaan untuk pelaksanaannya, perlu dipenuhi beberapa persyaratan penting, diantaranya adalah kegiatan yang diserahkan kepada pihak luar perusahaan tersebut bukan merupakan sumber inti bagi keunggulan kompetitif perusahaan, dan jika perusahaan melakukannya sendiri akan tidak efisien, yang disebabkan struktur biaya atau ketersediaan tenaga-tenaga profesional yang akan melaksanakannya. Karenanya, 
dengan menyerahkan kepada pihak luar perusahaan, akan lebih efisien dan lebih efektif.

Selanjutnya, departemen SDM melalui kebijakan-kebijakan yang ditetapkannya, juga bertindak sebagai koordinator bagi departemen-departemen fungsional perusahaan. Dengan kapasitasnya sebagai koordinator tersebut, departemen SDM bertanggung-jawab memfasilitasi terbentuknya kerjasama antar bidang-bidang fungsional perusahaan dan menghubungkan berbagai kepentingan individual maupun unit kerja dalam perusahaan, melalui penilaian kinerja karyawan, pengaturan karir, kebijakan kompensasi dan insentif, pembentukan tim kerja lintas fungsi dan lain sebagainya.

Dewasa ini, terjadi pergeseran peran fungsi-fungsi MSDM dan Deapartemen SDM dalam perusahaan secara signifikan. Pesatnya perubahan lingkungan ekonomi, yang ditandai dengan fenomena seperti globalisasi dan deregulasi pasar, perubahan permintaan investor dan pelanggan, dan peningkatan kompetensi pasar produk secara terus-menerus, menuntut peran fungsi-fungsi MSDM dan departemen SDM yang lebih besar ketimbang hanya menangani fungsi-fungsi personalia. Menurut Lancourt dan Savage (1995), fungsi-fungsi SDM harus mulai beralih kepada peranperan baru mereka, yaitu: (1) Penggeseran tanggung-jawab fungsional yang semakin banyak kepada manajer lini, (2) Menjadi mitra kerja bagi manajer lini, (3) Fokus pada pengembangan karir dan kompetensi, (4) Membayar keahlian dan (5) Organisasi yang lebih egaliter.

Demikian pula Schuller (1990), berpendapat bahwa diperlukan reposisi pada fungsi departemen SDM. Reposisi ini harus mampu mendesain peran baru, kompetensi baru, dan pola hubungan baru antara departemen SDM dengan manajer lini. Dengan reposisi ini, diharapkan departemen SDM tidak hanya menangani isuisu bisnis dan fokus pada pelanggan, melainkan juga memahami jalur produksi secara umum, sehingga mampu meningkatkan keefektifan dalam mengelola SDM dan bisnis yang digeluti. Dengan reposisi ini, departemen SDM mempunyai fungsi dan peran yang lebih strategis, yaitu :

1. Mengelola kemampuan karyawan, yaitu meningkatkan kemampuan karyawan berkaitan dengan perubahan tekhnologi dan perubahan organisasi.

2. Mengelola keragaman karyawan, yaitu kemampuan untuk menarik, memotivasi dan mempertahankan karyawan yang mempunyai latar belakang yang berbeda.

3. Mengelola tingkat persaingan yang semakin tinggi, berkaitan dengan keefektivan dan efisiensi perusahaan dalam penetapan harga, pengurangan biaya pengelolaan produk dan lain sebagainya.

4. Mengelola Globalisasi, berhubungan dengan terbukanya kesempatan yang sangat luas karena perubahan lingkungan persaingan dari pasar regional ke pasar global.

Menurut Ulrich (1998), dengan adanya transformasi dan reposisi fungsi departemen SDM, maka departemen SDM akan mempunyai tugas-tugas baru: 
1. Menjadi mitra bagi manajer senior dan manajer lini dalam menjalankan strategi, membantu menggerakkan perencanaan dari ruang konferensi hingga ke lapangan (pasar).

2. Menjadi ahli dalam menentukan cara pengorganisasian dan pelaksanaan pekerjaan, dapat menciptakan administrasi dengan lebih efisien untuk penghematan-penghematan biaya.

3. Menjadi pejuang bagi karyawan dan pekerja, dengan merefresentasikan keyakinan yang dimilikinya kepada manajer senior dan pada pekerjaan.

4. Menjadi agen perubahan transformasional secara terus menerus, membentuk proses dan budaya yang secara bersama dapat meningkatkan kapasitas organisasi selama perubahan terjadi.

\section{Meraih Sustained Competitive Advantage}

Para penulis yang menganut pendekatan sumberdaya perusahaan (ResourceBased View of the Firm's), memandang bahwa perusahaan bisa mengembangkan keunggulan kompetitif, dengan menciptakan nilai dengan bentuk dan cara yang jarang atau tidak bisa ditiru oleh para pesaing. Meskipun sumber-sumber keunggulan kompetitif tradisional seperti sumber daya alam, teknologi, skala ekonomi dan sebagainya mampu menciptakan nilai, namun pendapat yang didasarkan pada pandangan ini menyatakan bahwa sumber-sumber tersebut semakin mudah ditiru (Barney dan Wright, 1998).

Thurow (dalam Barney dan Wright, 1998) menyatakan bahwa salah satu alasan mengapa analisis bisnis sangat menghargai MSDM adalah karena perusahaan membutuhkan karyawan dalam menghadapi persaingan. Perusahaan berlombaIomba untuk mencari cara mempertahankan keuggulan mereka dalam jangka waktu lama dan yang tidak mudah ditiru oleh pesaing mereka. Perusahaan berusaha untuk meraih keunggulan kompetitif dengan beberapa cara, yaitu: menciptakan nilai (Value) perusahaan melalui fungsi MSDM., menciptakan kelangkaan nilai MSDM (Rareness), Menciptakan karakteristik MSDM yang tidak mudah ditiru (Immitability), dan Menciptakan keefektifan Organisasi (Organization). Pendekatan ini lebih dikenal dengan pendekatan VRIO, dalam rangka mencapai keunggulan kompetitif perusahaan yang berkelanjutan.

\section{Menciptakan Nilai Lembaga /Perusahaan}

Reicheld (dalam Barney dan Wright, 1998), berpendapat bahwa karyawan merupakan kontributor terbesar bagi perusahaan, sehingga karyawan harus diperlakukan sebagai mitra. Selain itu perusahaan yang mengelola SDM secara efektif memiliki tingkat profitabilitas yang tinggi, produktivitas tinggi, nilai pasar tinggi, dan pertumbuhan laba per saham yang tinggi pula. Usaha untuk menciptakan nilai ini antara lain dilakukan melalui penurunan biaya produk yang dihasilkan. Mengurangi biaya dan memperbaiki mutu produk merupakan dua cara yang biasa digunakan untuk memenuhi kepuasan konsumen, namun pelayanan yang baik juga 
merupakan faktor penting yang dapat mempengaruhi kepuasan konsumen. Schlesinger dan Zornitsky (1991) menyatakan bahwa kepuasan kerja dapat menyamakan persepsi karyawan dan konsumen tentang kualitas. Torhow dan Wiley (dalam Barney dan Wright, 1998) menyatakan bahwa sikap karyawan terhadap kepuasan kerja merupakan ukuran kinerja perusahaan. Penelitian terbaru dari Huselid (1995); Mac Duffie (1995); Youndt et al. (1996), menyatakan ada dua dasar implementasi MSDM. Pertama, praktik SDM penting bagi perusahaan dalam rangka mengembangkan modal, tenaga kerja dan perjanjian tenaga kerja. Kedua, praktik manajemen secara langsung mempengaruhi kualitas kerja yang dapat memberikan nilai pada perusahaan.

Dari beberapa pendapat mengenai nilai yang diberikan SDM dalam meraih keunggulan kompetitif, dapat ditarik beberapa kesimpulan. Pertama, untuk memperoleh nilai MSDM, perusahaan harus mengupayakan kepuasan konsumen yang diciptakan melalui kepuasan karyawan. Kedua, dengan kepuasan karyawan memungkinkan penghematan biaya seminimal mungkin. Hal ini didukung oleh pendapat Wright et al. (1996) yang menyatakan bahwa praktik dan fungsi MSDM menimbulkan biaya untuk organisasi. MSDM dapat mempengaruhi prestasi perusahaan secara efisien melalui pengembangan aset sumberdaya manusia yang merupakan sumber keunggulan kompetitif.

\section{Menciptakan Kelangkaan Nilai}

Kelangkaan nilai (rareness) dalam MSDM perusahaan mengandung maksud bahwa karakteristik SDM dan MSDM yang dimiliki adalah bermutu dan tidak dimiliki/dilakukan oleh perusahan lain. Hal ini merupakan salah satu aset penting dalam persaingan. Jadi setiap perusahaan harus dapat memiliki dan mengembangkan praktik-praktik MSDM secara inovatif yang berbeda dengan perusahaan lain. Sebagai contoh praktik MSDM yang banyak dilakukan saat ini adalah memfokuskan pada tenaga penjualan individual (personal selling) sebagai fungsi keunggulan kompetitif, dengan mempekerjakan karyawan penjualan yang menarik (atractive), muda dan mempunyai basis pendidikan sarjana. Praktik-praktik seperti ini terbukti mampu meningkatkan kinerja keuangan perusahaan dan tingkat turnover karyawan yang rendah.

Strategi pengembangan praktik-praktik MSDM dan SDM yang langka memerlukan usaha yang sungguh-sungguh, terutama sekali, harus linked dengan strategi bisnis perusahaan. Jika strategi yang dijalankan perusahaan adalah strategi deferensiasi, maka pengembangan praktik-praktik MSDM yang berbeda dengan perusahaan-perusahaan pesaing menjadi sebuah keharusan. Strategi ini mempersyaratkan tersedianya karyawan-karyawan yang memiliki kemampuan mengenali pasar dan memiliki kapabilitas teknis serta $R$ \& $D$ yang sangat baik. Karenanya praktik-praktik MSDM yang diterapkan perusahaan harus mampu 
merekrut dan mempertahankan karyawan-karyawan yang memiliki kapabilitas dan keahlian khusus, yang tidak dimiliki perusahaan pesaing.

\section{Karakteristik MSDM yang Tidak Mudah Ditiru}

Nilai dan karakteristik langka MSDM perusahaan akan memberikan keuntungan normal dalam jangka pendek, tetapi jika perusahaan lain meniru karakteistik ini, maka ia tidak dapat memberikan keuntungan yang lebih lama. Karenanya, perusahaan harus mampu mengembangkan karakteristik MSDM yang tidak mudah ditiru (immitability) oleh pesaingnya dengan menitik-beratkan pada pentingnya social complex seperti sejarah maupun kebiasaan perusahaan dalam meraih keunggulan kompetitif di masa lalu. Becker dan Gerhart (1996) menyatakan bahwa pengaruh MSDM pada kinerja perusahaan merupakan sebuah kemampuan yang tidak bisa ditiru. Alasan sulitnya meniru strategi MSDM yang sangat berakar pada organisasi, yang sangat berpengaruh adalah causal ambiguity dan path dependence.

Alasan lain adalah cukup sulit untuk bisa memahami mekanisme penghasil nilai dari praktik-praktik kebijakan MSDM. Untuk meniru sistem yang kompleks kita perlu memahami bagaimana elemen-elemen yang terdapat dalam sistem tersebut berinteraksi, atau apakah elemen tersebut melibatkan adanya bentuk non-linier yang kompleks atau apakah pengaruh-pengaruh yang dihasilkan bersifat additif atau multiplikatif. Tanpa adanya pemahaman tentang bagaimana suatu sistem MSDM bekerja, maka kita tidak akan bisa menirunya. Selain itu, sistem SDM merupakan sistem yang path dependence. Sistem-sistem tersebut terdiri dari beberapa kebijakan yang dikembangkan sepanjang waktu dan tidak bisa dibeli begitu saja oleh para pesaing. Pesaing mungkin bisa memahami bahwa suatu sistem tertentu sangat berharga namun tidak bisa melakukan imitasi atau peniruan secara langsung karena memerlukan waktu untuk menerapkan strategi-strateginya. Lebih jauh lagi, mungkin terdapat batasan-batasan kemampuan pihak manajemen untuk bisa melakukan replikasi dengan baik atas sejumlah elemen kompleks yang terdapat dalam sistem tersebut, seperti budaya dan hubungan antar pribadi.

\section{Menciptakan Keefektifan Organisasi Pendidikan}

Wright dan Snell (1994) berpendapat bahwa praktik-praktik MSDM secara strategis membutuhkan pengelolaan yang terkoordinasi dengan beberapa subfungsi. Untuk mengetahui keefektivan strategi MSDM yang dilaksanakan, maka perlu diketahui seberapa besar MSDM berpengaruh terhadap kinerja organisasi secara keseluruhan. Praktik-praktik MSDM menurut Dyer dan Holder (1988), akan terangkai dilaksanakan secara lengkap dan saling menguatkan. Logika perangakaian ini cukup jelas, karena kinerja SDM merupakan fungsi dari kemampuan dan motivasi sehingga cukup beralasan apabila pihak perusahaan berusaha meningkatkan kedua aspek tersebut, dan kinerja MSDM merupakan fenomena yang terbatas (Hackman; 1985), 
artinya kinerja tersebut kemungkinan baru akan maksimal bila dipengaruhi oleh kegiatan non-independen yang cukup banyak (MacDuffie, 1995).

Pengaruh MSDM terhadap kinerja organisasi dalam pengertian yang paling sederhana merupakan suatu peningkatan efisiensi. Secara tradisional, MSDM sebagai fungsi bisnis, dilihat sebagai biaya yang harus diminimalkan yang menjadi sumber penghematan potensial. Karena biaya tenaga kerja tetap menjadi biaya operasi terbesar dalam sebagian besar organisasi dan perampingan jumlah tenaga kerja menjadi strategi utama dalam melakukan restrukturisasi dan penurunan biaya.

\section{Praktik-Praktik MSDM terhadap Kinerja Organisasi}

Praktik-praktik MSDM diyakini mampu menghasilkan keunggulan kompetitif bagi perusahaan. Dalam banyak studi yang dilakukan (Dyer dan Reeves: 1995; Huselid et al.: 1997; Guest: 1997; Delaney dan Huselid: 1996; Snell dan Youndt: 1995; Bae dan Lawler: 2000), ditemukan adanya hubungan yang signifikan antara sistem dan praktik-praktik MSDM dengan kinerja perusahaan. Sistem dan praktikpraktik MSDM dapat menjadi sumber potensial untuk meningkatkan kinerja perusahaan, karena praktik-praktik MSDM dapat dijadikan sebagai sumber peningkatan efisiensi dalam perusahaan (Source of Efficiency) dan sekaligus menjadi sumber pencitaan nilai (Source of Value Creation). Sistem dan praktikpraktik MSDM diyakini merupakan sumber keunggulan kompetitif bagi perusahaan, karena sistem tersebut sukar ditiru oleh perusahaan lain atau dibeli begitu saja di pasar.

Pendapat yang selama ini berkembang luas di kalangan professional dan pelaku bisnis adalah bahwa departemen fungsional SDM merupakan sebuah pusat biaya (cost pool), dan praktik-praktik serta kebijakan-kebijakannya hanya menimbulkan biaya-biaya yang harus ditanggung oleh perusahaan. Pemahaman ini menggiring pada konsep Denumerator Management yang mengasumsikan bahwa kinerja optimal Departemen SDM dan aktivitas-aktivitasnya dicapai melalui efisiensi penggunaan SDM, bukan melalui penciptaan nilai tambah (value added) terhadap aktivitas-aktivitas MSDM itu sendiri.

Namun pemahaman ini mulai beralih kepada konsep yang mengatakan bahwa Departemen SDM merupakan sebuah pusat investasi (investment pool) bagi perusahaan. Sebagai sebuah pusat investasi, Departemen SDM melalui praktikpraktik dan kebijakan-kebijakannya diyakini mampu menciptakan nilai ekonomis bagi perusahaan (Kendrick dan Koppelman, dalam Steffy dan Maurer: 1988). Praktik-praktik dan kebijakan-kebijakan MSDM dikatakan produktif apabila mampu meningkatkan nilai ekonomis perusahaan, dan memenuhi tingkat kinerja yang diharapkan. Keyakinan bahwa sistem dan praktik-praktik MSDM merupakan sumber penciptaan nilai bagi perusahaan menggiring pada konsep yang oleh Hamel dan Prahalad (dalam Becker dan Gerhart, 1996) diistilahkan dengan konsep Numerator management. 
Konsep Numerator management memandang bahwa sistem dan praktikpraktik MSDM dapat dijadikan sumber keunggulan kompetitif yang berkelanjutan (sustainable competitive advantage) bagi perusahaan. Sistem dan praktik-praktik MSDM, menurut Becker dan Gerhart (1996) memiliki karakteristik-karakteristik yang langka (rare), bersifat khusus (specialized), berdaya-guna (appordable), dan sulit ditiru (difficult to imitate). Perusahaan dapat mengembangkan keunggulan kompetitif yang berkelanjutan melalui sumber-sumber tradisional seperti keunggulan sumberdaya alam, keunggulan tekhnologi, dan pencapaian skala ekonomis, yang juga menciptakan keunggulan kompetitif bagi perusahaan, namun keunggulan-keunggulan ini mudah sekali ditiru oleh perusahaan lain. Sedangkan sumber keunggulan kompetitif yang melekat pada SDM sukar ditiru oleh pesaing, dan oleh karena itu, strategi-strategi MSDM merupakan sumber sustainable competitive advantages yang mempunyai kedudukan penting bagi perusahaan.

Seperti yang diilustrasikan Gambar 3, dua hal yang membuat sistem dan praktik-praktik MSDM sukar ditiru oleh perusahaan lain adalah karena sistem dan praktik-praktik MSDM merupakan sistem yang bersifat causal ambiguity dan path dependent. Seperti yang dijelaskan oleh Becker dan Gerhart (1996), causal ambiguity mencerminkan bahwa sistem dan praktik-praktik MSDM memiliki karakteristik sebagai sebuah sistem yang kompleks. Sangat sulit memahami bagaimana praktik-praktik dan kebijakan-kebijakan MSDM saling berhubungan satu dengan yang lainnya, dan bagaimana memformulasikan praktik-praktik dan kebijakan-kebijakan MSDM yang tepat, sehingga mampu menciptakan nilai bagi perusahaan. Padahal, untuk meniru sistem yang kompleks, perlu dipahami bagaimana praktik-praktik dan kebijakan-kebijakan tersebut saling berinteraksi.

Karakteristik lain yang menyebabkan sistem dan praktik-praktik MSDM sulit ditiru, adalah path-dependency. Sistem dan praktik-praktik MSDM dikembangkan dalam kurun waktu tertentu (Becker dan Gerhart, 1996), dan melibatkan penyesuaian antara berbagai elemen yang saling berinteraksi di dalamnya. Perusahaan dapat saja membeli dan mengadopsi suatu sistem MSDM yang terbukti efektif diterapkan pada satu perusahaan, namun belum tentu akan efektif jika diterapkan pada perusahaan lain, pada rentang waktu yang berbeda. Setidaknya, sistem dan praktik-praktik MSDM tersebut tidak bisa diadopsi seketika. Diperlukan penyesuaian-penyesuaian terlebih dahulu, yang tentu saja membutuhkan rentang waktu yang cukup panjang, agar sistem dan praktik-praktik tersebut dapat bekerja. Seringkali terjadi, pada saat perusahaan berhasil menyesuaikan sistem dan praktikpraktik tersebut dengan elemen-elemen yang ada dalam perusahaan, sistem dan praktik-praktik tersebut sudah tidak mampu mengantisipasi perkembangan lingkungan yang begitu pesat, yang pada gilirannya tidak lagi dapat dijadikan sebagai sumber keunggulan kompetitif bagi perusahaan.

Penelitian-penelitian empiris telah membuktikan bahwa sistem dan praktikpraktik MSDM berpengaruh secara signifikan terhadap kinerja organisasional. Dalam 
menjelaskan hubungan antara sistem dan praktik-praktik MSDM dengan kinerja perusahaan, para peneliti umumnya terbagi menjadi tiga kelompok, yaitu para peneliti yang menggunakan teori tentang praktik-praktik terbaik MSDM (best practices), yang menggunakan teori konfigurasi (Configuracy Model), dan model praktik-praktik MSDM progresif (Progressive HRM Practices).

Teori praktik-praktik terbaik MSDM mengatakan bahwa, ada beberapa praktik MSDM terpilih, yang apabila diterapkan di organisasi manapun, akan memberikan pengaruh yang signifikan pada pencapaian kinerja organisasional. Jeffrey Pfefer, merupakan salah satu penggagas teori praktik-praktik MSDM terbaik. Menurut Pfefer dan Veiga (1999), untuk keberhasilan organisasi, tujuh praktik (seven practices) MSDM yang harus dilaksanakan, yaitu: Keamanan Pekerjaan (Employment Security), Mempekerjakan karyawan secara selektif (Selective Hiring), Pembentukan tim-tim mandiri dan desentralisasi sebagai unsur-unsur utama rancangan organisasi (Selfmanaged teams and decentralization as basic elements of organizational design), Menghitung tingginya kompensasi kontingen pada kinerja organisasional (Comparatively high compensation contingent on organizational performance), Pelatihan yang bersifat ekstensif (Extensive Training), Mengurangi perbedaan status (Reduction of status defferences), dan Penyebaran informasi (Sharing information).

Dyer dan Reeves (1995) menggunakan teori konfigurasi praktik-praktik MSDM. Teori ini menjelaskan hubungan antara serangkaian praktik-praktik MSDM dalam kaitannya dengan kinerja perusahaan, baik pada tingkat strategi yang lebih luas atau pada tingkat praktik-praktik MSDM tertentu. Hasil penelitian mereka menunjukkan bahwa serangkaian praktik-praktik MSDM memiliki pengaruh penting bagi peningkatan produktivitas tenaga kerja, dibandingkan kegiatan tunggal MSDM. Logika yang mendasarinya adalah 1) hasil kerja karyawan merupakan fungsi dari kemampuan dan motivasi, 2) hasil kerja karyawan akan maksimal bila dipengaruhi oleh kegiatan-kegiatan saling berhubungan (saling-ketergantungan), jadi bukan praktik-praktik MSDM yang terpisah. Dengan demikian kinerja terbaik perusahaan dapat diperoleh bila karyawan mendapatkan keterampilan, misalnya melalui pelatihan dan adanya beragam insentif yang bisa meningkatkan motivasi mereka.

Bukti-bukti yang lainnya mengenai hubungan antara praktik-praktik MSDM dengan kinerja perusahaan dikemukakan oleh Delaney dan Huselid (1996). Hasil penelitian mereka menunjukkan bahwa praktik-praktik progresif MSDM, seperti peningkatan skill karyawan melalui selektifitas staffing dan training; peningkatan motivasi karyawan melalui kompensasi insentif; serta perancangan struktur tugas dan pekerjaan yang baik melalui desentralisasi pengambilan keputusan dan hirarki vertikal, secara positif berhubungan dengan persepsi kinerja organisasi.

Guest (1997) meneliti hubungan antara strategi-strategi SDM dengan kinerja organisasi. Menurut Guest, Praktik-praktik MSDM yang inovatif dapat memberikan kontribusi terhadap peningkatan kinerja ekonomis perusahaan dengan syarat: 1) karyawan memiliki pengetahuan dan keahlian yang tidak dimiliki oleh pihak 
manajemen, 2) karyawan termotivasi untuk menerapkan pengetahuan dan keahlian yang mereka miliki, dan 3) strategi bisnis atau strategi produksi/operasional perusahaan dapat dilakukan oleh karyawan. Snell dan Youndt (1995) mengembangkan 3 pendekatan kendali (controll) MSDM yang dapat dilaksanakan oleh para eksekutif MSDM, yaitu praktik-praktik MSDM yang berdasarkan kendali perilaku, kendali hasil dan kendali masukan. Penelitian mereka terhadap 436 perusahaan Amerika Serikat menunjukkan bahwa praktik-praktik MSDM yang didasarkan pada kendali perilaku dan kendali masukan memiliki hubungan yang signifikan terhadap kinerja perusahaan. Namun praktik-praktik MSDM yang didasarkan pada kendali hasil memiliki hubungan yang tidak signifikan dengan kinerja perusahaan. Huselid et al. (1997) menemukan bahwa kapabilitas yang dimiliki manajer SDM berpengaruh terhadap efektivitas praktik-praktik MSDM dan pada akhirnya berpengaruh terhadap kinerja finansial perusahaan. Pengaruh ini disebabkan karena kegiatan-kegiatan teknis dan strategis MSDM dapat meningkatkan produktivitas, kualitas, profitabilitas, dan kelangsungan hidup organisasi. Hasil penelitian mereka pada perusahaan-perusahaan di Amerika Serikat membuktikan adanya hubungan yang signifikan antara keefektivan MSDM strategis dengan tingkat produktivitas karyawan, arus kas, dan nilai pasar perusahaan. Temuan ini memberikan implikasi bahwa: 1) Keahlihan dan kemampuankemampuan professional staff SDM sangat mendukung penerapan kegiatankegiatan MSDM strategis dan perlu dipertahankan pada saat perusahaan tengah mengalami pergeseran paradigma dalam MSDM, 2) Kemampuan-kemampuan yang berkaitan dengan bisnis merupakan kontributor utama terhadap pelaksanaan kegiatan-kegiatan MSDM strategis, dan pengembangan kemampuan-kemampuan tersebut di kalangan para professional SDM perlu ditingkatkan. Temuan ini menguatkan pendapat bahwa investasi pada SDM sangat perlu, karena dapat meningkatkan nilai perusahaan.

\section{PENUTUP}

\section{Kesimpulan}

Menghadapi lingkungan persaingan yang semakin ketat saat ini, perusahaan dituntut untuk menciptakan dan memiliki keunggulan kompetitif (competitive advantage). Perusahaan dapat mencapainya dengan berbagai cara, seperti dengan memiliki sumberdaya-sumberdaya fisik yang tidak dimiliki pesaing, investasi modal, kapabilitas inovasi, hak patent, pencapaian skala ekonomis (economic of scale), dan lain sebagainya. Namun keunggulan kompetitif yang diciptakan melalui sumberdayasumberdaya dan kapabilitas-kapabilitas tersebut hanya mampu bertahan dalam jangka waktu yang relatif singkat. Pesaing dengan mudah akan memiliki sumbersumber keunggulan kompetitif yang sama, dan selanjutnya membahayakan posisi bersaing perusahaan. 
Sumber-sumber yang mampu memberikan keunggulan kompetitif yang berkelanjutan (Sustainable Competitive Advantage), yang mampu memberikan keunggulan-keunggulan kepada perusahaan dalam waktu yang relatif lama. Untuk dapat memberikan keunggulan kompetitif yang berkelanjutan tersebut, suatu sumberdaya atau kapabilitas, menurut Barney dan Wright (1998), harus memiliki karakteristik-karakteristik bernilai, langka, tidak mudah ditiru, dan menciptakan keefektivan organisasi. Sejalan dengan penjelasan Beckert dan Gerhart (1996), sumber-sumber keunggulan kompetitif yang berkelanjutan harus memiliki karakteristik-karakteristik yang tepat-guna, langka, sulit ditiru dan bersifat khusus.

\section{Saran}

1. Praktik-praktik dan keputusan-keputusan di bidang MSDM diyakini mampu menciptakan keunggulan kompetitif yang berkelanjutan bagi perusahaan, karena sistem dan praktik-praktik MSDM memiliki karakteristik yang sulit ditiru.

2. Sistem dan praktik-praktik MSDM sukar ditiru oleh pesaing, karena mengandung dua unsur, yaitu Causal Ambiguity dan Path-Dependency. Keyakinan terhadap signifikansi peran MSDM dalam menciptakan keunggulan kompetitif yang berkelanjutan ini, telah mendapat dukungan secara luas, dan telah terbukti secara empiris. Dalam banyak penelitian, sistem dan praktik-praktik MSDM ditemukan secara signifikan mampu meningkatkan kinerja organisasional.

\section{DAFTAR PUSTAKA}

Buller, Paul.F, 1988, "Successful partnership: HR and strategic planning at eight top firms", Organizational Dynamics, 17 p. 27 - 43.

Camuffo, Arnaldo \& Giovanni Costa,? "Strategic Human Resources Management Italian Style", Academy of Management Review

Delery, John E. \& D. Halord Doty, 1996, "Modes of Theorizing in Strategic Human Resource Management: Tests of Universalistic, Contingency, and Configurational Performance Predictions", Academy of Management Journal, 39

Greer, Charles P. 2001, "Strategic Human Resources Management: A General Management Approach", Second Edition, Prentice Hall Inc, New Jersey

Kamoche, Ken, 1996, "Strategic Human Resources Management Within a Resources Capability View of the Firm", Journal of Management Studies, p. 213 - 233

Khatri, Naresh, 1999, "Emerging Issues in Strategic HRM in Singapore, International Journal of Manpower, 20 p. 516 - 530

Lado, Agustine A. \& Mary C. Wilson, 1994, "Human Resources Systems and Sustained Competitive Advantage: A Competency - Based Perspective", Academy of Management Review, 19 p. 699 - 727 
Lennick Hall, Chyntia \& Mark L. Lennick Hall. 1986. "Strategic Human Resources Management: A Review of the Literature and a Proposed Typology". Academy of Management Review, 13 p. 454 - 470

Mintzberg, Henry, 1986, "The Rise and fall of Strategic Planning". The Free Press, p. $293-321$.

Mueller, Frank, 1996, "Human Resources as Strategic Asset: An Evolutionery Resources Based Theory", Journal of Management Studies, p. 757 - 785

Rouse, Michael J \& Urs S. Daellenbach. 1999. "Rethinking Research Method for Resources Based Perspective: Isolating Sources of Sustainanble Competitive Advantage", Strategic Management Journal, 20 p. 497 - 494

Schuler, Randall S. \& Susan E. Jackson, 1987, "Linking Competitive Strategies with Human Resources Management Practices", The Academy of Management Executive, 1 p. 207 - 219

Wright, Patrick M. \& Scott A. Snell, 1998, "Toward Unifying Framework for Exploring Fit and Flexibility in Strategic Human Rssources Management", Academy of Management Review, 23 p. 756 - 772

Wright, Patrick M. \& Gary C. McMahan, 1992, "Theoretical Perspectives for Strategic Human Resources Management", Journal of Management, 18 p. 295 - 320. 